\title{
CULTURAL SECURITY OF UKRAINE
}

According to the National Security Strategy of Ukraine (Stratehiia..., 2020 ), priorities of the national interests of the Ukrainian state at the present stage of development are the following: defense of independence and state sovereignty; restoration of territorial integrity within the internationally recognized state border of Ukraine; social development, first of all development of human capital; protection of rights, freedoms and legitimate interests of the citizens of Ukraine; European and Euro-Atlantic integration. However, in our opinion, ensuring the development and sustainability of the cultural sphere, formation of a single Ukrainian socio-cultural space and creation of an innovative competitive Ukrainian cultural product should also be in the list of top national interests aimed at preservation and development of the Ukrainian state.

The theoretical basis of the study of cultural security of Ukraine are scientific developments on this issue; the legislation of Ukraine in the sphere of culture and information security; data of the all-Ukrainian census on the distribution of the population of Ukraine according to the language criteria; data from sociological surveys on the maintenance of the Ukrainian language as the only state and official language in Ukrainian society.

A set of general scientific methods was used in the study of the cultural security problems of Ukraine. Objectivity and systematicity principles laid the basis of the chosen methodology. Methods of scientific cognition of socio-political phenomena and processes were used, in particular: analysis, synthesis, systematization, empirical, systemstructural. The empirical method allowed us to generalize the factual material on the ethnopolitical and language situation in Ukraine. Through analysis, we examined the normative-legal framework, components, and peculiarities of cultural, language, and informational public policies of Ukraine. System analysis enabled the study of the cultural security of Ukraine as a holistic system of complex measures of the state and civil society structures aimed at achieving interethnic stability and consolidation of Ukrainian society.

\section{CULTURE AS A MARKER OF NATIONAL IDENTITY}

Culture permeates the system of national values of the state, and is one of markers of national identity. The core of ethnicity is contained in the cultural principles - myths, 
memories, values, symbols and characteristic styles of special historical configurations (Smith, 1978: 235), and cultural and linguistic differentiation is one of seven features that determine a nation, along with the following: territory and mobility; large size; external relations; group feelings and loyalty; civil rights, i.e. degree of politicization; economic integration (Smit, 2010: 97-98).

Nations and ethnic groups are created by (relevant) cultures, and it is "a particular culture inherent to the nation that distinguishes it from among other nations and is its presentation card in the international community" (Hibernau, 2012: 26). Awareness of common culture and history, love for the mother land, myths and symbols able to generate emotional ties - these are the "core of national identity," "the main components of national identity," without which there is no social solidarity and cohesion (Hibernau, 2012: 200). Accordingly, education of national feelings (through myths, symbols, holidays, and historical education), formation of a single cultural space and development of a common for all citizens social culture, which includes the state language - are among the key tools for formation of national consolidation (Kolodii, 2013: 42).

In the process of modeling national identity, archetypes (in form of certain trends and tendencies) are also important: human experience of collective existence is recorded in them. Reconstruction of archetypes helps to interpret certain processes as national and cultural phenomena. Carriers of national identity in culture must "recognize themselves" in the past, perceive history in familiar images. Cultural memory is an active regeneration of cultural content in the space of traditions and innovations. Mythologization is manifested in endowing the event with uniqueness, capacity to determine the fate of the nation, and then the event becomes "eternal" (tradition) (Demchuk, 2017: 57).

National cultural (essentially polyethnic) space is structured by a set of various semantic and symbolic forms of reproduction of cultural codes. They are personified by individual and collective consciousness, real practices and potentially possible ideas, systematize and accumulate the accumulated experience of human life, and form an image of man and their place in the world, characteristic to the historical type of culture. The cultural code is dynamic in nature, it is able to change itself depending on the specific historical conditions of development of a socio-cultural system. Dynamic nature of the cultural code is due to the functions it performs in society, in particular:

- social inheriting (cultural code determines special system-forming factors, some of which ensure reproduction of generations, as well as conformity of forms and ways of life; others have the ability to change themselves, which helps to adapt to changing environmental conditions);

- formation of identity (inherited cultural code conveys clear principles and opportunities for human identification in their cultural environment);

- social construction (information and semiotic specificity of the cultural code makes it possible to reproduce the own specificity in symbolic forms under new conditions) (Sushyi, 2012).

Taking into the account all the above, culture is an important factor of national consolidation and formation of national identity through creation of a single socio-cultural space of the state, which can be interpreted as cultural activities of social actors for 
creation of cultural values, development of abilities of individuals and servicing their creative activities, communication - wide-spreading, preservation and public use of all types of cultural values.

The basis of socio-cultural space is culture (individual, national, universal) as a set of achievements of human heritage, and the unifying factors are language, cultural and historical traditions, customs, rituals, morality, religion, politics, law that create the national character of socio-cultural space. At the same time combination of such factors as "environment - values - socio-cultural space - education - organizations and movements - traditions - family" is the most efficient, as these factors, through their specific role and sequence, create fundamentally new opportunities for spiritual development of personality (Koretska, 2003: 19).

In the process of forming socio-cultural space there is socio-cultural self-identification of the individual occurs - a manifestation of personal activity in course of activities aimed at meeting its value, cognitive, economic and spiritual needs through selfreference and self-representation as a subject of a particular sector of socio-cultural space (Kurhuzov, 2004). Thus, inclusion of the person into culture occurs on four levels: mental; individual and cultural; subcultural and transsubcultural (Oleksiuk, 2004). They determine the sources of formation of the spiritual potential of the individual in the current socio-cultural situation. In particular, the mental level is an area of autonomous individual microcultural space, where one's own attitudes towards the cultural realities play a special role. At the individual-cultural level, cultural consciousness and self-consciousness are realized, which illuminates the inner essence of oneself as a subject, contemplates and learns oneself and their spiritual world, evaluates their capabilities, abilities and acts of activity. At these two levels, the main sources of spiritual potential of the individual are self-learning, self-education, and self-improvement. Subcultural level of inclusion of the individual into culture is a close to the individual sociocultural environment, subcultural and national-cultural space. It is the nationalcultural space that provides interpersonal interactions and communication within social groups. The focus of this level is the direct influence of social institutions - family, education system, art institutions, and media.

Taking into account the above, we can conclude that the spirituality expressed in language, religion and system of moral and cultural values is the basis of self-organization and self-preservation of any ethnic group. Linguistic and cultural factors influence the functioning of social organization in any of its forms, are reflected in the public consciousness, are passed down from generation to generation and serve a platform for formation of national identity. Formation of a single socio-cultural space involves formation of common inclusive national cultural identities. That is why within a single socio-cultural space social culture of the nation - a set of certain cultural symbols, beliefs, norms and values, which are used by official institutions and society as a whole, regardless of its division into ethnocultural groups - is formed. Such a culture is acceptable to the whole nation, covers subcultures of different ethnic and social groups, and is based on a single state language. After all, language is an important sign of identification of an individual, group, state as a whole. It serves as a mean of expression and formation of national self-consciousness, satisfies cultural needs of the people, and is one of the most important consolidating signs of identity. 
Self-identification of the individual occurs within the relevant cultural and linguistic tradition that has developed in a particular society. At the same time, this tradition goes beyond this society into the global socio-cultural space due to language embodied in information that represents and retransmits a lot of values, norms, role and behavioral guidelines that significantly influence this process (Kurhuzov, 2004). It is the language structures that initially "immerse" the individual in such a being, the subject of which necessarily reveals themselves in the world, realizes themselves as a subject of their own self-determination. After all, a person becomes a person largely due to language. Language makes a person involved into spirituality, ensures formation of the human aspect in man (Karaulna, 1998). Language is the most ethnicized basic feature of the nation, closely related to such an acute social phenomenon as national culture, common nature of the territory (Mala entsyklopediia etnoderzhavoznavstva, 1996, 18).

Therefore, language appears not only as a mean of communication and a way of expressing the ambiguity of cultural meanings, but is perhaps one of most important features of ethnicity and a manifestation of national mentality. Language preserves genetic memory of the nation, its traditions and rituals.

Intercultural communication of ethno-subjects of society and interethnic socialization play an important role in the process of forming of socio-cultural space of the nation. In the process of intercultural communication there is a mutual assimilation of cultural elements occurs, which promotes integration processes, mutual cultural exchange and enrichment of the nation's culture, strengthening national self-awareness. Interethnic socialization is entry of a representative of a certain ethnic group into the system of relations with other ethnic groups, mastering by a person, group, ethnic group of knowledge, methods, activities in the process of interaction, exchange of ethnic material and spiritual values.

Intercultural communication is an indicator of development of culture, it reveals its ability to perceive other-cultural elements on the basis of new for a particular socio-cultural organism forms; demonstrates the ability to transmit the own values into other cultures. Intercultural communication is a generator of cultural meanings, a basic element of formation, reproduction and transmission of certain cultural components and a culture as a whole. It enshrines cultural and social significance in the form of symbols, signs and linguistic expression, creates a semiotic space that ensures interpenetration and openness of cultures and is a condition for conscious activity of people and interaction among them. Symbolic form of intercultural communication, which is a mechanism of cultural memory, also has an important meaning (Bakhov, 2012).

Intercultural interaction at the national level is possible only in the presence of national unity, which emerges both on monoethnic and polyethnic grounds through joint economic activity and state-political unification. It is complemented by formation of the relevant culture. At this, national culture is a set of traditions, norms, values and rules of conduct common to the members of one nation, state; it covers subcultures of different social groups that may not be present in a particular ethnic culture. In the process of intercultural interaction such tendencies as acculturation and deculturation can appear. Acculturation is mutual assimilation of cultural elements; it promotes integration processes, mutual cultural exchange and enrichment of cultures. But at the same time national self-awareness strengthens, attempting to consolidate national specificity. But when during long-term 
communication with another culture there is a loss of the main, essential part of the native culture - deculturation - there appears uncertainty or instability. Such phenomena lead to certain socio-cultural problems of intercultural communication (Shcherbyna, 2013).

Therefore, from the point of view of culturological approach, national identity includes language, mentality, image of the world, mythology, cultural memory, religious and civic position. If the nation has a common territory of residence, cultural traditions, historical memory, self-consciousness, religion and language - these the key factors constitute and consolidate the nation. If we talk about formation of Ukrainian national identity, this process is based on ethnocultural features, as ethnocultural component of the Ukrainian nation - ethnic in nature - predominates political one.

Threats to the cultural interests of the nation can provoke challenges to national identity and, consequently, endanger its existence. Ukraine's historical experience is evidence. After all, the centuries-old policy of de-ethnicization and assimilation of the Ukrainian ethnos by states that included Ukrainian lands in different historical periods has led to deformations of the national linguistic-cultural and linguistic-information space and loss of Ukrainian national identity in some regions. Therefore, today Ukraine is characterized by blurring and ambivalence of national identity. Unfortunately, during the years of Ukraine's independence, the policy of leveling the main national integrating and identification features, in particular, Ukrainian national values, cultural features, the status of the Ukrainian language as the state language, and falsifying the history of Ukraine, continued by pro-Russian political and business circles. As a result, it led to the deepening of the spiritual crisis of Ukrainian society, the crisis of linguistic and cultural identity, predominance of regional identities over national, uncompleted formation of the Ukrainian civil nation; ignoring of Ukrainian national interests and national values, loss of values and regulatory guide marks; dominance of the Russian language in key areas of socio-political life of Ukraine; political speculation over language issues; growth of annexationist and separatist sentiments among the population of the Eastern regions of Ukraine, inspired by the Russian Federation; occupation of Crimea by the Russian Federation and Russian aggression against Ukraine in Donbas.

\section{LANGUAGE ASPECT OF CULTURAL SECURITY OF UKRAINE}

In Ukraine, after proclamation of independence, after formal acknowledgement of the priority status of the Ukrainian language as the state language along with the actual dominance of the Russian language in key areas of socio-political life, Ukrainian language became rather symbolic. Therefore, the language issue has become one of the most controversial since Ukraine's independence. During the years of the existence of the state, Ukrainian language has been threatened with transformation from a state language to a minority one.

According to the results of the All-Ukrainian Census of 2001, major part (77.8\%) out of the total population of Ukraine (48 million 457 thousand) were Ukrainians. The largest ethnic minority were Russians (17.3\%). Belarusians, Moldovans and Crimean Tatars accounted for $0.5 \%$ each; Bulgarians $-0.4 \%$, Hungarians, Romanians and Poles $-0.3 \%$, Jews $-0.2 \%$ (Pro kilkist ta sklad naselennia..., 2001). At the same time, ac- 
cording to the results of the All-Ukrainian Census of 2001, Ukrainian language was considered the native language by about $70 \%$ of the population of our state (Pro kilkist ta sklad naselennia..., 2001).

The language issue in Ukraine became relevant with the beginning of Russia's war against the state. According to the State Statistics Service of Ukraine as of January 1, 2017, the population of Ukraine, excluding the temporarily occupied territory of the Autonomous Republic of Crimea and the city of Sevastopol, was 42,481,972 persons (Chyselnist naiavnoho naselennia..., 2017). Data from opinion polls conducted in March 2017 by leading Ukrainian sociological centers, such as: Kyiv International Institute of Sociology, Rating, SOCIS, Razumkov Center, showed that $90.6 \%$ of the population considered themselves Ukrainians by nationality, 6,3\% - Russians, and $2.7 \%$ of citizens considered themselves representatives of other national minorities. At this, young people aged from 18 to 24 declared their Ukrainian national identity most often (Bilshe $90 \%$ hromadian..., 2017). However, only $50.5 \%$ used Ukrainian language as the main language of everyday communication. $24 \%$ of respondents used Russian as the main language of everyday communication (Table 1). Traditionally, the Eastern and Southern regions of Ukraine remained Russian-speaking. Ukrainian language was spoken by the population living in the West (97.2\%) and Southwest (91.6\%) of the country (Bilshe $90 \%$ hromadian..., 2017). Therefore, it was the Russian-speaking regions that became the focus of the Russian Federation's attack, while the Ukrainian-speaking ones escaped such a threat: it proves that the language is capable to consolidate the nation, making it more resilient to external challenges and threats to national security.

Table 1

Distribution of population by language criterion according to age categories in Ukraine as of 2017

\begin{tabular}{|c|c|c|c|c|c|c|}
\hline \multirow{2}{*}{$\begin{array}{c}\text { Language of } \\
\text { communication at home }\end{array}$} & \multicolumn{5}{|c|}{ Age category } & \multirow{2}{*}{$\begin{array}{c}\text { In Ukraine, } \\
\text { total }\end{array}$} \\
\hline & $18-24$ & $25-35$ & $36-45$ & $46-55$ & $56+$ & \\
\hline Ukrainian & $47.6 \%$ & $49.1 \%$ & $49.1 \%$ & $50.6 \%$ & $52.9 \%$ & $50.5 \%$ \\
\hline Russian & $25.1 \%$ & $25.4 \%$ & $24.5 \%$ & $24.6 \%$ & $22.2 \%$ & $24.0 \%$ \\
\hline Ukrainian and Russian & $25.1 \%$ & $23.9 \%$ & $24.5 \%$ & $23.4 \%$ & $23.6 \%$ & $24.0 \%$ \\
\hline Other & $1.7 \%$ & $1.4 \%$ & $1.5 \%$ & $1.3 \%$ & $1.0 \%$ & $1.3 \%$ \\
\hline Refused to answer & $0.2 \%$ & $0.2 \%$ & $0.3 \%$ & $0.1 \%$ & $0.2 \%$ & $0.2 \%$ \\
\hline
\end{tabular}

Source: Bilshe 90\% hromadian..., 2017.

According to an all-Ukrainian poll conducted by Kyiv International Institute of Sociology in May 2017, 64\% of respondents believed that the state should primarily support Ukrainian language, 19\% voted in favor of support of "all languages to equal extent" and $2 \%$ of respondents believed that the Russian language needed special support. Also, the majority (61\% of respondents) considered assistance in "spreading Ukrainian language in all areas of life" to be the main task of the state language policy. $59 \%$ of respondents supported Ukrainian as the only language of communication in public institutions, $54 \%$ believed that in trade institutions and services area request in Ukrainian should always be responded in Ukrainian as well (Zakon pro movu...). Therefore, the society has actually formed a consensus on the priority of using Ukrainian language as the state language in all spheres of life. 
In recent years, there has been a significant increase in support for the status of Ukrainian language as the only state and official language: if in May 2014 such support was demonstrated by a third part of respondents (34\%), and in May, 2019 - by the majority of respondents $(65 \%)$. At the same time, the share of those who believe that both Ukrainian and Russian should be the state languages in Ukraine (18\%) and those who are positive about giving Russian language an official status in some regions of Ukraine (15\%) has significantly decreased. However, regional differences in responses still remained. The Western region continues to show the most active support for the status of Ukrainian language as the only state language (87\%). Proponents of proclamation of two official languages in Ukraine are still concentrated in the South and East (34\% and $27 \%$ respectively) (Doslidzhennia...).

About half of the respondents to the Poll of 2019 have a positive attitude to the Law of Ukraine "On Ensuring the Functioning of the Ukrainian Language as the State Language" (Pro zabezpechennia..., 2019) - (42\%), a fifth part of respondents (23\%) expressed a negative attitude, the same number of respondents are neutral $(21 \%) .14 \%$ of respondents could not answer. It should be emphasized that according to the Law of Ukraine "On Ensuring the Functioning of the Ukrainian Language as the State Language," the status of Ukrainian language as the sole state language makes it mandatory to use it throughout Ukraine in the exercise of powers by public authorities and local governments, as well as in other spheres of public life defined by this Law. Ukrainian as the only state language performs the functions of the language of interethnic communication, is a guarantee of protection of human rights for every Ukrainian citizen regardless of their ethnic origin, and is a factor of unity and national security of Ukraine. The main tasks of this Law are:

- protection of the state status of Ukrainian language;

- assertion of the Ukrainian language as a language of interethnic communication in Ukraine;

- provision of functioning of the state language as an instrument of unification of Ukrainian society, a means of strengthening of the state unity and territorial integrity of Ukraine, its independent statehood and national security;

- ensuring of use of the Ukrainian language as the state language on the entire territory of Ukraine in the areas of public life defined by this Law, as well as in international communication during performance of representative functions by Ukrainian officials;

- ensuring the development of Ukrainian language to strengthen national identity, preserve national culture, traditions, customs, historical memory and ensure its further functioning as a state-building factor of the Ukrainian nation;

- support of Ukrainian language by promoting:

a) knowledge of Ukrainian language by citizens of Ukraine;

b) development of Ukrainian sign language as the main or one of the main means of communication of sign language speakers;

c) use of Ukrainian language in accordance with the requirements of Ukrainian spelling and other standards of the state language;

d) use of Ukrainian words, phrases and terms instead of foreign ones if there are equivalents in Ukrainian language; raising awareness of citizens about such equivalents; 
e) prevention of vulgarization of Ukrainian language and its mixing with other languages;

f) dissemination of knowledge about Ukrainian language and its role in the development of Ukrainian and European cultures;

g) popularization of dialects of Ukrainian language and preservation thereof;

h) study of Ukrainian language in Ukraine and abroad;

- spreading Ukrainian language in the world and assisting in meeting language needs of foreign Ukrainians and citizens of Ukraine living or temporarily staying outside Ukraine (Pro zabezpechennia ..., 2019).

The majority of respondents to the 2019 Poll believed that the new Language Law promotes the development of Ukrainian language (39\%). One-fifth of respondents believed that the new Language Law will not affect the use of languages in Ukraine (21\%). According to $17 \%$ of respondents, the new Language Law oppresses the rights of people who do not speak Ukrainian but other languages. $14 \%$ of respondents consider the new Language Law to be a reason for disputes and conflicts. $9 \%$ of respondents could not answer. In the West, the new Language Law is much more often considered positively (61\%), and in the East and South - negatively (34\% and 32\%, respectively). In the West, the new Language Law is generally considered to be more conducive to the development of Ukrainian language (55\%), while in the South and East there are more widespread concerns about oppression of non-Ukrainian speakers (26\% and 25\% respectively) (Doslidzhennia...). At the same time, at home and in the family circle, approximately the same shares of respondents usually speak Russian and Ukrainian (49\% each). Ukrainian language dominates in the sphere of formal communication - in educational institutions (53\%), while Russian language predominates in informal communication - with friends, acquaintances (52\%) and on the Internet (56\%). It is expected that Ukrainian language is more commonly used in the West and in the Center, as well as in small settlements, while Russian language is more common in the East and South, as well as in large cities. The age distribution is also interesting: Ukrainian language turned out to be the most popular among young people (Doslidzhennia...).

Despite the declaration of the state status of Ukrainian language, analysis of the language situation in the country shows the existence of political speculation about its use, which is contrary to the interests of national security of Ukraine and threatens its sovereignty. To eliminate such a threat, it is necessary to expand the scope of Ukrainian language, stimulate formation and protection of national linguistic-cultural and linguistic-information space. The state must ensure unconditional implementation of the constitutional regulation on comprehensive development and functioning of Ukrainian language in all spheres of public life throughout Ukraine.

\section{ETHNOPOLITICAL ASPECTS OF CULTURAL SECURITY OF UKRAINE}

Ukrainian nation, like any other, is a dynamic social organism: it is whole and divided at the same time. It was formed, is constantly formed and changed in the unity and struggle of opposites, by actualization, strengthening or harmonization of immanent contradictions, through manifestation, aggravation, resolution or "freezing" 
of artificially constructed or provoked contradictions. At the heart of this dynamic are differences in human personal and group interests and values and related identities - ethnic, cultural, linguistic, religious, political and geopolitical, regional, social, age and others.

Ethnopolitical system belongs to the social type of systems; organization and development of a social system falls under no exact laws and patterns, as conditions and means of social stability are largely determined by subjective factors and are prerogative of individual and collective intelligence (Balanda, 2006: 23). Given this, development of social formations is difficult to predict because it can occur in different ways under the same conditions. Sometimes those ways lead to the destruction of the system. Therefore, ensuring security and maintaining stability in the ethnopolitical system is a complex and difficult task.

Actualization of ethnic ties is accompanied by demands and attempts by ethnic minorities and their elites to divide the territory, resources, and completely restructure the system of government in fair way. This often leads to interethnic and ethnopolitical conflicts of varying intensity. Taking this into account, there is a need to distinguish the direction within the framework of national security - ethnopolitical security. Ethnopolitical security can be considered as a set of state measures aimed at preventing and counteracting destabilizing factors in the field of ethnopolitical relations, which can destabilize the standing of the titular state-building nation, ethnic and national minorities, indigenous peoples and the state as a whole.

Condition of protection of the main objects of ethnopolitical security is characterized by ethnopolitical stability and ethnopolitical development, ability of the state and ethno-subjects to respond to threats that cause interethnic tensions, manifestations of interethnic enmity, interethnic, ethnopolitical, ethnoterritorial conflicts that threaten the sovereignty of the state, adequately (Etnopolitychna bezpeka Ukrainy, 2015: 13).

A dangerous factor in the ethnopolitical sphere of Ukraine is the loss by the titular ethnic group of ethnic identity based on the language factor due to the lack of proper language policy, which has led to a high level of russification of the media space in Ukraine. Ukraine also has a demographic deficit caused by migration and falling birth rates. This can lead to disturbance in the internal balance of society and difficulties in the mutual adaptation of indigenous people and immigrants. It is immigration that can compensate for the low birth rate in the country. This policy has been repeatedly resorted to by European countries and United States to increase the population of working age. However, immigration policy affects the transformation of not only economic but also social relations. The mass migrants flow changes ethnic, religious and linguistic structure of the population of the state, creates a conflict of ethnic values between immigrants and indigenous people.

The most threatening trend, which can lead to the loss of territorial integrity, state sovereignty and disintegration of the state, is separatism. It presupposes the desire of an ethnic group or inhabitants of a certain territory to separate on legal grounds in the form of autonomy or an independent state. According to experts from the National Institute for Strategic Studies, the main factors intensifying separatist movements in Ukraine are: 
- historical: long being of certain parts of the current state territory of Ukraine as part of other states, where a special regional identity has been formed;

- religious: local combination of ethnic and religious factors in certain regions, which significantly strengthens regionalist practices;

- ethnic: more russified South-Eastern part of the country and more Ukrainian NorthWestern part;

- economic: existence of a significant gap in the levels of social and economic development among regions, which stimulates dissatisfaction of richer territories with unfair, in their opinion, distribution of national income (Potentsialni zahrozy rehionalnoho separatyzmu...).

One of the main reasons for intensification of separatist tendencies in Ukraine is the long-term practice of interfering in Ukraine's ethnopolitical sphere of neighboring states, in particular Russia (in the Autonomous Republic of Crimea, Donbas) and Hungary (in Zakarpattia region) and the simplified procedure for the citizens of Ukraine for granting their respective citizenship, organizational and informational support of their national minorities in order to disintegrate Ukrainian society.

During all the years of independence of Ukraine, the most ethno-conflicting region was Crimea. The main reason for this situation was that for many decades Crimea had been the object of Russian colonization. This ensured the quantitative dominance of Russians after Crimean Tatars had been evicted. Trying not to exacerbate ethnopolitical contradictions in Crimea, the central Ukrainian government did not interfere in the sphere of ethnopolitical relations of the peninsula. This contributed to the strengthening of the Russian ethnocultural environment. Crimean Tatars were dissatisfied with that situation, and after returning to the peninsula, they demanded that the Ukrainian state fully rehabilitate their rights, including ethnocultural and property rights. And also Ukrainians who found themselves in the status of a minority on the peninsula. But since most of them were russified, their actual presence did not correspond to the quantitative indicators of the Census. That is how apparent ethnopolitical stability on the peninsula managed to be maintained during all the years of independence of Ukraine, translating ethnopolitical conflict between major ethnic communities into a latent condition (Aslanov, 2006: 316). The autonomy within Ukraine formed on the peninsula in 1991, although was formally defined as territorial, was in fact Russian national-territorial autonomy (Maiboroda, 2002: 30).

The hybrid war of the Russian Federation against Ukraine has become an open manifestation of violation of the state sovereignty of Ukraine. This conflict between Ukraine and Russia is presented as having a distinct ethnic nature: protection of one ethnic group from violent actions of another. As a result of informational, propaganda and force components of Russia's hybrid war, interethnic relations in Ukraine were aggravated under the slogan of Ukrainian government's attack on the cultural rights of ethnic Russians and the need for Russian intervention to protect them. It is permanent ethnopolitical instability in Crimea and its strengthening by Russia blocking Ukraine's European integration aspirations, provoking Russian minority of Crimea to conflict with the Ukrainian state in the direction of Crimea's withdrawal from Ukraine and joining Russian Federation, lack of purposeful state ethnopolitics, that led to the loss of territorial integrity and state sovereignty of Ukraine. 
Numerous statements by Hungarian officials about the need for the Hungarians of Zakarpattia to seek autonomy also present a threat to ethnopolitical national interests of Ukraine. In particular, in May 2014, after winning the election, Hungarian Prime Minister Viktor Orban, speaking in the Hungarian Parliament, stated that Hungarians abroad have the right to dual citizenship and autonomy. This thesis was repeated in March 2017 by the Deputy Prime Minister of Hungary, Zsolt Shemien, at the presentation of the book entitled "Minority Rights. Representation of interests. Autonomy," and by participants of the Budapest forum of Hungarian deputies from the Carpathian Basin countries, where Hungarian Parliament Speaker Laszlo Kover, Foreign Affairs Minister Peter Siarto, Secretary of State for National Policy Arpad Janos Potapy were present (Tuzhanskyi, 2017). If the statement in 2014 was applied to all Hungarians abroad, the one in 2017 made the emphasis on Hungarians living in Ukraine and on the potential threats to them in connection with the Russian aggression against the Ukrainian state.

About 150,000 ethnic Hungarians live compactly in Ukraine, which is $10-12 \%$ of the population of Zakarpattia region. They have broad cultural autonomy and are represented in public authorities at all levels. However, this is not enough for Hungary. It insists on the restoration of the Prytysianskyi constituency in Zakarpattia. We are talking about geographical boundaries of Berehovo and Vynohradiv districts, where the vast majority of Ukrainian Hungarians live along Tysa River. Official Budapest wants them to elect their representative to the Verkhovna Rada of Ukraine. This Hungarian constituency in Zakarpattia existed in the parliamentary elections of 1998, but was liquidated after a change in electoral legislation. Restoration of Prytysiansky constituency may be the first step towards the national-territorial autonomy of Ukrainian Hungarians.

The status of autonomy can be used by national minorities as an intermediate link to sovereignty and separation with outside support. In particular, in the beginning the number of minority members in a given territory is increased to the most possible amount through ethnic mobilization or political and economic incentives. Subsequently, the national minority demands autonomy with the broadest rights, after which it tries to exercise its right to self-determination (Onishchenko, 2009: 633). Such a scenario, reinforced by armed intervention, was used by the Russian Federation regarding the annexation of the AR Crimea. Therefore, given the escalation of ethnopolitical relations in Ukraine due to the armed conflict in Donbas and the loss of Crimea, expanding the rights of national minorities, including Hungarian, in the direction of granting territorial autonomy poses a threat to the national interests of Ukraine.

\section{CHALLENGES TO THE CULTURAL SECURITY OF UKRAINE AND WAYS TO OVERCOME THEM}

The hybrid war of the Russian Federation against Ukraine, which is also carried out on the cultural front by falsifying the history of Ukraine (Perepysuvannia istorii..., 2014), appropriating Ukrainian cultural achievements, numerous insults towards Ukrainian identity, propaganda against Ukrainian language and Ukrainian nation as 
a whole, made the problem of ensuring the cultural security of Ukraine as acute as never before. The long-term lack of a proper state policy to support the development of Ukrainian language and culture, patriotic education, has caused such negative phenomena as:

- presence of imperial-totalitarian rudiments in the public consciousness, which generate discord both in the interpretation by certain categories of Ukrainian society of its historical past, and in the attitude to the Ukrainian spiritual and cultural heritage;

- low level of spirituality and morality in the society;

- uncompleted formation of the national linguistic and cultural space, stability of its value basis to external intervention;

- lack of unified state information and educational policy, transformation of the information space into a field of manipulation of public consciousness, production of values disorientation;

- insufficient level of harmonization of legislation and management practices in the field of formation of civil stance with the legislation and best practices of European countries;

- lack of uniform standards for processes, subjects, their competence and authority, quality of activities in the field of national-patriotic education;

- lack of communication between public authorities and civil society structures on issues of national and patriotic education;

- lack of qualified human resources in public authorities, local governments, educational institutions for organization and implementation of measures for nationalpatriotic education, underdeveloped grassroots in the system of educational processes coordination;

- low level of logistical support and infrastructure development in the field of national-patriotic education (Stratehiia natsionalno-patriotychnoho vykhovannia...). In addition to the internal challenges to cultural security, a number of external negative factors influence at ethnocultural development of the Ukrainian state-building nation and formation of Ukrainian national identity, in particular:

- Russia's hybrid war against Ukraine, aimed at the loss of territorial integrity and state sovereignty of Ukraine, aggravation of interethnic relations, deformation of information and cultural space due to the dominance of Russian information products in the regions of Ukraine adjacent to Russia, manipulation of Ukrainians' consciousness, falsification of Ukrainian historical memory;

- intensive globalization processes that require new approaches to public policy to preserve and develop cultural peculiarities of Ukrainian nation, as globalization trends create an unstable identity, which appears to be a conscious reaction of the individual to external social circumstances, which destroys ethnic boundaries and leads to deconsolidation of the society;

- formation of information and cultural space of Ukraine under the influence of foreign information flows, filled with foreign to the Ukrainian nation mental values and ideals and low quality information products that erode Ukrainian national identity, undermine the foundations of Ukrainian cultural identity, act as a powerful factor of national oppression. Within such an information space, society becomes an indefinite amorphous mass of consumers. 
Centuries-old cultivation of inferiority of Ukrainians as a nation, displacement of Ukrainian language from the spheres of education, science, culture, office work, reduction of cultural practices only to ethnographic manifestations, have led to the problems in forming a single socio-cultural space, in particular, the following:

- lack of a unified conceptual vision of the development of the humanitarian sphere at the state level;

- imperfection of educational, linguistic and cultural public policy in the context of cultivating Ukrainian national values, development of spirituality of Ukrainian nation, assertion of Ukrainian language as the state language, patriotic education of Ukrainian youth;

- low level of development of cultural industries and formation of competitive Ukrainian national cultural products;

- dominance of foreign cultural and artistic products within the cultural and information space of Ukraine;

- media of Ukraine, which are the main information channels for influencing public consciousness, are under control of financial and industrial groups that do not always take a pro-Ukrainian national position and act in the interests of foreign countries.

Unregulated and uncontrolled presence of foreign mass media in the Ukrainian information space has created a powerful channel of influence on the consciousness of Ukrainian society, through which there is an active dissemination of foreign values, ideals, meanings, cultural codes and patterns, especially language - of all the things that form the identity, but not Ukrainian identity in this case. The dominance of these products significantly reduces the Ukrainian language space, destroys the way of thinking, distorts the consciousness of Ukrainian citizens, instills foreign stereotypes, and inspires the feeling of inferiority (Karlova, 2011).

All these above challenges to the cultural security of Ukraine, non-consolidation of Ukrainian society, violation of territorial integrity and state sovereignty of Ukraine, neglect by some citizens of Ukrainian language as a state one, require public policy to ensure cultural security of Ukraine, assertion of Ukrainian language as a state one, cultivation of Ukrainian cultural and historical national values in Ukrainian society as the fundamental foundations of the Ukrainian national identity, integration and consolidation of Ukrainian society.

Given these challenges and threats to the cultural security of Ukraine, development of Ukrainian culture should be at the center of state interests, national policy, national security, and the following should be on the agenda of the state policy:

- development and implementation of an integration conceptual model of state policy on the formation of Ukrainian national identity;

- development and adoption of the Strategy of Cultural Security of Ukraine and the State Program of its implementation;

- application of effective management mechanisms to protect Ukrainian information and cultural space from external negative cultural influences;

- implementation of language policy aimed at assertion of Ukrainian language as the only state language, formation of a national cultural and communication environment, in which national consolidation would take place and Ukrainian national identity would be formed; 
- implementation of an effective state policy in the humanitarian sphere aimed at formation of a qualitative practice-oriented system of education, creation of competitive cultural products, expansion of Ukraine's participation in European and world cultural cooperation; integration of Ukrainian culture into the world cultural space while preserving Ukrainian cultural identity;

- implementation of the state information policy aimed at formation and strengthening of the national self-consciousness of Ukrainian citizens, stimulation of the active process of social, political, mental integration of the population into the Ukrainian society; restoration of Ukrainian control in the information space in the temporarily occupied territories as a condition for victory in the war of identities;

- formation of a system of national-patriotic education, especially in the military formations of Ukraine, which should be carried out on the basis of national-historical principles and traditions of Ukrainian nation and become a significant obstacle to the spread of nihilistic sentiments among the population;

- ensuring intercultural communication and interethnic socialization of ethnic subjects of Ukrainian society;

- development and implementation of the target program for creation of Ukrainian cultural "brand" and competitive Ukrainian cultural innovative products, their promotion in the world.

\section{CONCLUSIONS}

The hybrid war of the Russian Federation against Ukraine has exacerbated a number of problems in Ukrainian society, and, in particular, in the cultural sphere. Today the problem of consolidation of the society and formation of the national identity is acute in Ukraine. Culture plays a dominant role in the constitution of the nation. Culture preserves national memory, self-esteem and social harmony of the nation, carries foundations for formation of national identity. Culture encourages various forms of creative self-expression and, at the same time, learning and renewal of traditions, promotes development of creative economy, innovation policy and active public participation in building of a modern and democratic state. Intensive globalization processes - that cause an unstable nature of identity, incompleteness of formation of Ukrainian national linguistic and cultural space, lack of stability of its values basis to external intervention, imperfection of educational, linguistic and cultural policy in the context of cultivating Ukrainian national values, development of Ukrainian spirituality, assertion of Ukrainian language as the state language, low level of development of cultural industries and, accordingly, the dominance of foreign cultural and artistic products within the Ukrainian cultural and information space - have raised the issue of ensuring the cultural security of Ukraine.

Formation of Ukrainian national identity and consolidation of Ukrainian nation should be based on the national values of Ukrainian state-building nation (state Ukrainian language, state symbols, culture, historical memory), national-patriotic education, democracy, human rights and rule of law, preservation of cultural identity of 
indigenous people and national minorities of Ukraine. Ukrainian language, cultural and historical values and traditions, morality, religion of the Ukrainian state-building nation should form the foundations of Ukrainian socio-cultural space.

Assertion and development of Ukrainian language as the state language - determining factor and main feature of the identity of Ukrainian nation; ensuring intercultural communication and interethnic socialization of ethnic subjects of Ukrainian society; formation of a system of national-patriotic education; formation of qualitative practice-oriented system of education; creation of competitive innovative cultural products, expansion of Ukraine's participation in European and world cultural cooperation; restoration of Ukrainian control in the information space of the temporarily occupied territories - it must become the priorities of the state policy of ensuring cultural security of Ukraine.

\section{REFERENCES}

Aslanov S. A. (2016), Polityko-pravovi zasady etnopolitychnoi stabilnosti derzhavy v umovakh hlobalnykh vyklykiv, Kyiv.

Bakhov I. S. (2012), Mizhkulturna komunikatsiia v konteksti hlobalizatsiinoho dialohu kultur, "Visnyk Natsionalnoi akademii Derzhavnoi prykordonnoi sluzhby Ukrainy", Vyp. 2, http://nbuv. gov.ua/UJRN/Vnadps_2012_2_3 (12.11.2020).

Balanda A. L. (2006), Sotsialni aspekty natsionalnoi bezpeky Ukrainy, „Derzhavna bezpeka Ukrainy", No. 1 (5).

Bilshe 90\% hromadian (2017), Bilshe 90\% hromadian nazvaly sebe ukraintsiamy za natsionalnistiu, http://www.pravda.com.ua/news/2017/06/17/7147226/ (24.10.2020).

Chyselnist naiavnoho naselennia Ukrainy na 1 sichnia 2017 roku, http://database.ukrcensus.gov.ua/ PXWEB2007/ukr/publ_new1/2017/zb_chnn_0117.pdf (21.10.2020).

Demchuk R. (2017), Mifolohema u konteksti modeliuvannia natsionalnoi identychnosti, "Kulturolohichni idei", No. 11.

Doslidzhennia: movna sytuatsiia v Ukraini, "KANTAR", https://ns-ua.com/news/doslidzhennyamovna-situatsiya-v-ukrayini (16.11.2020).

Etnopolitychna bezpeka Ukrainy (2015), Etnopolitychna bezpeka Ukrainy: polityko-pravovi mekhanizmy protydii etnopolitychnii dezintehratsii derzhavy: Naukova zapyska, Kyiv.

Hibernau M. (2012), Identychnist natsii, Kyiv.

Karaulna N. V. (1998), Dukhovnist i samovyznachennia osobystosti, in: Materialy „Dniv nauky -1998 ", Kyiv.

Karlova V. (2011), Mistse ta rol humanitarnoho prostoru derzhavy u formuvanni natsionalnoi samosvidomosti, „Visnyk natsionalnoi akademii derzhavnoho upravlinnia pry Prezydentovi Ukrainy”, Vyp. 1, http://nbuv.gov.ua/UJRN/Vnadu_2011_1_7 (3.10.2020).

Kolodii A. (2013), Sotsiietalna kultura yak chynnyk natsionalnoi konsolidatsii, in: Konsolidatsiia ukrainskoho narodu: konstytutsiino-pravovi aspekty. Zbirnyk statei za materialamy naukovopraktychnoi konferentsii 28 liutoho-1 bereznia 2013 r., Lviv.

Koretska A. I. (2003), Sotsialno-osvitni chynnyky formuvannia dukhovnosti sobystosti v suchasnomu ukrainskomu suspilstvi, Kyiv. 
Kurhuzov A. O. (2004), Mova yak zasib sotsiokulturnoi samoidentyfikatsii osobystosti, Zaporizhzhia.

Maiboroda O. M (2002), Etnopolitychna sytuatsiia v Ukraini: rehionalnyi vymir, in: Spryiannia poshyrenniu tolerantnosti v polietnichnomu suspilstvi, Kyiv.

Mala entsyklopediia etnoderzhavoznavstva (1996), Mala entsyklopediia etnoderzhavoznavstva, Kyiv.

Oleksiuk O. M. (2004), Pidhotovka fakhivtsiv sotsiokulturnoi sfery v dukhovno-svitohliadnomu dyskursi, http://www.knukim.edu.ua/conferences_2004_proceedings_oleksyuk.htm/ (8.10.2020).

Onishchenko K., Klasyfikatsiia ta osoblyvosti polityko-pravovoho statusu terytorialnykh avtonomii, „Derzhava i pravo”, Vyp. 45.

Perepysuvannia istorii - skladova propahandystskoi viiny Putina - ekspert, https://www.radiosvoboda.org/a/26696327.html (5.12.2020).

Potentsialni zahrozy rehionalnoho separatyzmu v Ukraini, http://www.niss.gov.ua/articles/1478/ (15.09.2020).

Pro kilkist ta sklad naselennia Ukrainy (2001), Pro kilkist ta sklad naselennia Ukrainy za pidsumkamy Vseukrainskoho perepysu naselennia 2001 roku, http://2001.ukrcensus.gov.ua/results/ general/nationality/ (10.09.2020).

Pro zabezpechennia funktsionuvannia ukrainskoi movy yak derzhavnoi (2019), Zakon Ukrainy, Vidomosti Verkhovnoi Rady (VVR), № 21, st.81.

Shcherbyna V. M. (2013), Mizhkulturna komunikatsiia u suchasnomu sotsiokulturnomu prostori, "Visnyk Natsionalnoho tekhnichnoho universytetu Ukrainy «Kyivskyi politekhnichnyi instytut»", No. 2.

Smith A. (1978), The Diffusion and Nationalism: Some Historical and sociological perspectives, "British Journal of Sociology", Vol. 29, No. 2.

Smit E. D. (2010), Kulturni osnovy natsii: iierarkhiia, zapovit i respublika, Kyiv.

Stratehiia (2020), Stratehiia natsionalnoi bezpeky Ukrainy. «Bezpeka liudyny-bezpeka Ukrainy», Ukaz Prezydenta Ukrainy vid 14 veresnia 2020 r. No. 392/2020, https://www.president.gov. ua/documents/3922020-35037 (8.12.2020).

Stratehiia (2015), Stratehiia natsionalno-patriotychnoho vykhovannia ditei ta molodi na 2016-2020 roky, Ukaz Prezydenta Ukrainy vid 13 zhovtnia 2015 roku No. 580/2015 http://zakon3.rada. gov.ua/laws/show/580/2015 (18.11.2020).

Sushyi O. (2012), Kulturno-symvolichni zasady natsionalnoi identychnosti, „Derzhavne upravlinnia: teoriia ta praktyka", No. 2.

Tuzhanskyi D. (2017), Shcho khovaietsia za ideieiu avtonomii uhortsiv? Ryzyky ta mozhlyvosti dlia Ukrainy, https://www.eurointegration.com.ua/articles/2017/03/29/7063755/view_print/ (15.09.2020).

Zakon pro movu: fakty, pohliady ta dumky, https:/vseosvita.ua/news/zakon-pro-movu-fakti-pogladita-dumki-2518.html (4.12.2020).

\begin{abstract}
Condition and problems of ensuring the cultural security of Ukraine were analyzed. Hypothesis that ensuring development and sustainability of the cultural sphere, formation of a single Ukrainian socio-cultural space based on Ukrainian language, historical memory, spiritual values, cultural traditions is one of priority national interests of the Ukrainian state
\end{abstract}


at the present stage was put forward. Research methodology is based on the principles of objectivity and systematicity. During the research, methods of scientific learning of sociopolitical phenomena and processes were used, in particular: analysis, synthesis, systematization, empirical, and system-structural methods. The authors prove that cultural traditions, historical memory, self-consciousness and language are key factors that constitute and consolidate a nation, and threats to the nation's cultural interests can jeopardize its existence. It was found that the centuries-old policy of de-ethnicization and assimilation of Ukrainian ethnos by foreign states has led to deformation and russification of the national linguistic and cultural space of Ukraine, loss of ethnic identity based on the language factor of the titular Ukrainian ethnos, deepening the spiritual crisis of Ukrainian society. It is determined that the key threats in the field of cultural security of Ukraine today are the following: Russia's hybrid war against Ukraine, formation of information and cultural space of Ukraine under the influence of foreign information flows, imperfection of humanitarian policy in the context of cultivating Ukrainian national values, low level of development of cultural industries, dominance of foreign cultural and artistic products, control over Ukrainian media by financial and industrial groups that often take an anti-Ukrainian position. It was proved that the measures to assert and popularize Ukrainian language as the state language, ensure intercultural communication and interethnic socialization of ethnic subjects of Ukrainian society, formation of national-patriotic education, creation of competitive innovative cultural products and their popularization in the world should be priority directions of the state policy of ensuring cultural security of Ukraine.

Keywords: culture, cultural security, Ukraine, nation, language, national identity, threats to cultural security, linguistic and cultural space

\section{BEZPIECZEŃSTWO KULTUROWE UKRAINY}

\section{STRESZCZENIE}

Artykuł poświęcony został zagadnieniu bezpieczeństwa kulturowego Ukrainy, jego obecnej kondycji oraz zagrożeń. Autorzy stawiają tezę, iż ukraińska racja stanu wymaga zapewnienia rozwoju i trwałości sfery kulturowej państwa, stworzenia jednolitej ukraińskiej przestrzeni społeczno-kulturowej opartej na języku ukraińskim, pamięci historycznej, wartościach duchowych oraz tradycjach kulturowych. Zdaniem autorów, wspomniane powyżej tradycje kulturowe, pamięć historyczna, samoświadomość oraz język są kluczowymi czynnikami konstytuującymi i scalającymi naród, a zagrożenia dla jego interesów kulturowych mogą też zagrażać istnieniu samego narodu. W artykule stwierdzono, iż wielowiekowa polityka wynarodowienia i asymilacji etnosu ukraińskiego przez obce państwa doprowadziła do deformacji oraz rusyfikacji narodowej przestrzeni językowej i kulturowej Ukrainy. Co więcej, w efekcie powyższych procesów doszło do utraty tożsamości etnicznej w oparciu o czynnik językowy części narodu ukraińskiego oraz do głębokiego kryzysu duchowego społeczeństwa ukraińskiego. Za kluczowe zagrożenia w obszarze bezpieczeństwa kulturowego Ukrainy uznano dziś: wojnę hybrydową Rosji z Ukrainą, kształtowanie się przestrzeni informacyjnej i kulturowej Ukrainy pod wpływem zagranicznych kanałów informacyjnych, niski poziom rozwoju ukraińskiego przemysłu rozrywkowego, dominację zagranicznych ośrodków kulturalnych i artystycznych oraz sprawowanie kontroli nad ukraińskimi mediami poprzez podmioty zagraniczne, często reprezentujące antyukraiński punkt widzenia. Wykazano również, że działania na rzecz propagowania i upowszechniania języka ukraińskiego 
jako języka państwowego, kształtowanie edukacji narodowo-patriotycznej, tworzenia konkurencyjnych i innowacyjnych produktów kultury oraz ich popularyzacja poza granicami Ukrainy powinny stać się priorytetowymi kierunkami państwowej polityki bezpieczeństwa kulturalnego Ukrainy.

Słowa kluczowe: kultura, bezpieczeństwo kulturalne, Ukraina, naród, język, narodowa identyczność, zagrożenia kulturalnemu bezpieczeństwu, językowo-kulturalna przestrzeń 